\title{
Ventriculoperitoneal Shunt Infections in Children: Demographical, Clinical Findings and Evaluation of Thrombocyte Parameters
}

\author{
Çocuklarda Ventriküloperitoneal Şant Enfeksiyonu: \\ Demografik, Klinik Özellikler ve Tanıda Trombosit Parametrelerinin \\ Değerlendirilmesi
}

\author{
Özlem Özgür Gündeşlioğlu' , Zeliha Haytoğlu², Kerem Mazhar Özsoy³, Derya Alabaz'1, Emine Kocabaş' \\ ' Division of Pediatric Infectious Diseases, Cukurova University School of Medicine, Adana, Turkey \\ ${ }^{2}$ Department of Pediatrics, Cukurova University School of Medicine, Adana, Turkey \\ ${ }^{3}$ Department of Neurosurgery, Cukurova University School of Medicine, Adana, Turkey
}

\begin{abstract}
Objective: We investigated demographic, clinical and laboratory characteristics of children with ventriculoperitoneal (VP) shunt infection in this study. The aim of this study was to make a comparison between the values obtained before and after treatment, and those obtained before treatment and of the control groups in terms of platelet count, mean platelet volume (MPV) and platelet distribution width (PDW) values in the diagnosis of VP shunt infection.
\end{abstract}

Material and Methods: In this study, medical records of patients diagnosed with VP shunt infection between the years 2015-2018 were retrospectively reviewed. Healthy children of similar age groups were selected as the control group. The platelet count, MPV and PDW values of the patients were compared before and after treatment, and before treatment and with the control group.

Results:13 (39.4\%) female and 20 (60.6\%) male patients who were diagnosed with VP shunt infection were included in this study. The median age of the patients was 8 months (min-max: 1-106 month). The most common complaints were nausea and vomiting (66.7\%) followed by loss of appetite (57.6\%) and fever (51.5\%). Growth in the cerebrospinal fluid (CSF) culture of 23 (69.7\%) patients was detected and the most common cause was Staphylococcus epidermidis (57.6\%). At admission, patients with VP shunt infection had mean follow-up platelet counts of $521.969 \pm 143.697 \mu \mathrm{L}$ (min-max: 256.000-854.000 $\mu \mathrm{L}$ ) and 25 patients $(75.7 \%)$ had thrombocytosis. There was statistically significant
Özet

Giriş: Bu çalışmada ventriküloperitoneal (VP) şant enfeksiyonu gelişen çocuk hastaların demografik, klinik, laboratuvar özellikleri incelenmiştir. VP şant enfeksiyonu tanısında trombosit sayısı, ortalama trombosit hacmi (OTH), trombosit dağılım aralığı (TDA) değerlerinin tedavi öncesi, tedavi sonrası ve tedavi öncesi ile kontrol grubunun karşılaştırılması amaçlanmıştır.

Gereç ve Yöntemler: Bu çalışmada 2015-2018 yılları arasında VP şant enfeksiyonu tanısı alan hastaların dosyaları geriye dönük olarak incelendi. Benzer yaş grubundan sağlıklı çocuklar kontrol grubu olarak seçildi. Hastaların tedavi öncesi, sonrası ve tedavi öncesi ile kontrol grubu trombosit sayısı, OTH ve TDA değerleri karşılaştıııldı.

Bulgular: Bu çalışmaya VP şant enfeksiyonu tanısı alan 13 (\%39.4)'ü kız, 20 (\%60.6)'si erkek 33 hasta dahil edildi. Hastaların median yaşı 8 ay (minmaks: 1-106 ay) idi. En sık başvuru yakınması bulantı-kusma (\%66.7) olup bunu iştahsızlık (\%57.6) ve ateş (51.5) izlemekte idi. Hastaların 23 (\%69.7)'ünde beyin omurilik sıvısı (BOS) kültüründe üreme tespit edildi ve en sık etken Staphylococcus epidermidis (\%57.6) idi. Ventriküloperitoneal şant enfeksiyonu olan hastaların yatışta bakılan ortalama trombosit değerleri $521.969 \pm 143.697 \mu \mathrm{L}$ (min-maks: 256.000-854.000 $\mu \mathrm{L}$ ) olup 25 (\%75.7)'inde trombositoz mevcut idi. Hastaların tedavi öncesi ve sonrası trombosit sayıları arasında anlamlı fark bulundu $(\mathrm{p}=0.001)$. Tedavi öncesi ve sonrası OTH değerleri karşılaştırıldığında tedavi öncesi ortalama
Correspondence Address / Yazışma Adresi

Özlem Özgür Gündeşlioğlu

Çukurova Üniversitesi Tıp Fakültesi,

Çocuk Enfeksiyon Hastalıkları Bilim Dalı,

Adana-Türkiye

E-mail: ozlemozgur1978@yahoo.com OCopyright 2018 by Pediatric
Infectious Diseases Society -Available online at www.cocukenfeksiyon.org ○Telif Hakkı 2018 Çocuk Enfeksiyon Hastalıkları Derneği -Makale metnine www.cocukenfeksiyon.org web sayfasından ulaşılabilir 
difference between before and after treatment platelet counts of the patients $(p=0.001)$. When MPW values were compared between before and after treatment, the mean MPW value at before treatment was 9.58 $\mathrm{fL}$ and the mean MPW value at after treatment was $9.87 \mathrm{fL}$, which was statistically significant $(p=0.027)$. The difference between PDW values before and after treatment was not statistically significant. When MPW and PDW values of the control group and the patients were compared, there was no statistical difference.

Conclusion: In our study, there was no statistical difference between MPW and PDW values in healthy children and patients with VP shunt infection. However, in patients with VP shunt infection, although thrombocytosis was present at the beginning of the treatment, the values after treatment were within normal limits. At the beginning of treatment, MPW values were found to be lower than after the treatment. In the case of VP shunt infections, in order to use the platelet parameters (MPW, PDW) for diagnosis, prospective studies with more patients are needed.

Keywords: Ventriculoperitoneal shunt infection, platelet, mean platelet volume, platelet distribution witdh

\section{Introduction}

In the treatment of hydrocephalus, ventriculoperitoneal (VP) shunt application is the main treatment method. Despite the positive developments in the treatment of hydrocephalus with VP shunt, complications such as infection are the most important problems in the treatment. The rate of infection development in children with ventriculoperitoneal shunt has been reported as 5-18\% according to the studies (1-6). Small age, especially prematurity, previous VP shunt infection, shunt insertion reason (purulent meningitis, intracranial hemorrhage, meningomyelocele), surgeon experience, duration and technique of surgery, compliance with sterility and having a story of 3 or more shunt changes are risk factors for VP shunt infection development $(2,3,7)$. Coagulase-negative staphylococci are the most common cause of ventriculoperitoneal shunt infections and infection is usually caused by skin transmission $(3,8)$. In VP shunt infections in children, some patients may have no signs or symptoms. As a result of infection-induced shunt dysfunction, headache, nausea and vomiting due to intracranial pressure increase may occur. Local signs and symptoms may occur due to infection developed at the tip of the shunt catheter. Early diagnosis of ventriculoperitoneal shunt infections is important for prognosis (2).

In recent years, the diagnostic value of platelet parameters has been investigated in many infectious diseases. Platelet activation is an important step in the immunopathogenesis of inflammatory diseases. Platelet count, mean platelet volume (MPV), platelet distribution range (PDR) changes are indicators of platelet activation and function. In cases leading to inflammations such as infection, megakaryocytes increase due to thrombopoietic stress. The increase in megakaryocytes is
OTH değeri $9.58 \mathrm{fL}$ iken tedavi sonrası ortalama OTH değeri $9.87 \mathrm{fL}$ idi ve fark anlamlı idi $(p=0.027)$. Tedavi öncesi ve sonrası TDA değerleri açısından fark anlamlı değildi. Kontrol grubu ile hastaların tedavi öncesi OTH ve TDA değerleri karşılaştırıldığında fark anlamlı bulunmadı.

Sonuç: Çalışmamızda sağlıklı çocuklar ile VP şant enfeksiyonu olan hastalarda OTH ve TDA değerleri arasında anlamlı fark bulunmadı. Ancak VP şant enfeksiyonu olan hastalarda tedavi başlangıcında trombositoz mevcut iken tedavi sonrası değerlerin normal sınırlara geldiği görüldü. Tedavi başlangıcında OTH değerlerinin tedavi sonrasına göre daha düşük olduğu saptandı. VP şant enfeksiyonlarında trombosit parametrelerinin (OTH, TDA) tanıda kullanımı için daha fazla hasta ile yapılan prospektif çalışmalara intiyaç vardır.

Anahtar Kelimeler: Vetriküloperitoneal şant enfeksiyonu, trombosit, ortalama trombosit hacmi, trombosit dağılım aralığı

usually acompaned by increased platelet count and MPV in infectious diseases. Platelet distribution range indicates platelet volume difference. Evaluation of mean platelet volume as well as PDR provides better definition of platelet volume distribution. Because platelet counts are measured routinely together with MPV and PDR values in the complete blood count, platelet parameters are very easy and inexpensive $(9,10)$. Although platelet parameters have been used in a number of studies, different results can be obtained in some technical cases, such as the type of hematology analyzer, anticoagulant administered, and time from sampling to analysis. Although MPV and PDR have increased due to reactive thrombocytosis in infectious diseases, contradictory results have been reported in many studies (11). In this study, we aimed to evaluate the demographic, clinical and laboratory features of pediatric patients with VP shunt infection and to compare the platelet count, MPV, and PDR values before treatment with the control group.

\section{Materials and Methods}

This study included children aged 0-18 years who were diagnosed with VP shunt infection followed-up at the Pediatric Infection Service, General Pediatrics Service, Neurosurgical Service, and Brain Surgery Intensive Care Unit between 2015 and 2018. None of the patients included in the study had any disease affecting platelet function and platelet count. The files of the patients were analyzed retrospectively. Age, gender, date and cause of VP shunt placement, clinica and laboratory features, BSF findings, length of hospitalization, treatment applied, previous VP shunt infection and VP shunt changes of the patients were recorded on the course forms. 
The diagnosis of VP was achieved with symptom (headache, nausea, vomiting, seizure, change of consciousness, fever) and findings (fever, change of consciousness, redness of the shunt, meningeal irritation sign) or with BOS taken from the shunt reservoir or with direct puncture from the ventricle of the patient with possible shunt infection. If there is reproduction in the cerebrospinal fluid or there is no reproduction in BOS, $>10 / \mathrm{mm}^{3}$ WBC and low glucose levels ( $<45 \mathrm{mg} / \mathrm{dL}$ ) and high protein levels (> $100 \mathrm{mg} / \mathrm{dL}$ ) in BOS direct examination were considered as VP shunt infection (12). The patient with possible VP shunt infection according to the clinical and laboratory results was diagnosed wit VP shunt infection by the pediatric infection specialist, excluding the other infection diseases. In patients who were diagnosed with ventriculopretoneal shunt infection, infected shunt was removed, appropriate antibiotic treatment was started and reservoir was inserted into the ventricle and BSF was discharged. Complete blood count, C-reactive protein (CRP) levels, erythrocyte sedimentation rate (ESR), serum procalcitonin levels, BSF cell count, BSF glucose, BSF protein levels and BSF culture reproduction of the patients at the time of admission were recorded. Platelet values of the patients before discharge (before VP shunt insertion) were recorded. The platelet count, MPV and PDR values of the patients were compared in two groups: before hospitalization and before discharge.

Thirty-three healthy children who were not diagnosed with infection or inflammatory disease from a similar age group who applied to the General Polyclinic were selected as the control group and the complete blood count of the control group children was recorded. The platelet count, MPV and PDR values of children with VP shunt infection and the ones of the control group were compared. Platelet counts over $450.000 \mathrm{~mm}^{3}$ value were accepted as thrombocytosis (13).

\section{Statistical Analysis}

Data were evaluated using SPSS version 20.0 (SPSS, Inc., Chicago, IL, USA). Data were analyzed in terms of distribution normality. Descriptive statistics of the variables with normal distribution were expressed as mean \pm standard deviation, and the ones with abnormal distribution were expressed as median (minimum-maximum). When the group amount was two, independent sample $t$ test was applied for the variables complying with the normal distribution and the dependent sample t-test was applied to the dependent groups. Statistical significance was accepted as $p<0.05$ in all data.

\section{Results}

The study included thirty-three patients with VP shunt infection of which 13 (39.4\%) were female and 20 (60.6\%) were male. The median age of the patients was 8 months (min-max: 1-106 months). $93.3 \%$ of the patients included the ones with
Table 1. Demographic and clinical characteristics of patients with ventriculoperitoneal (VP) shunt infection

\begin{tabular}{|c|c|c|}
\hline \multirow{2}{*}{$\begin{array}{l}\text { Characteristics } \\
\text { Gender } \\
\text { Female } \\
\text { Male }\end{array}$} & \multicolumn{2}{|c|}{$\begin{array}{l}\text { Number of } \\
\text { patients (n) } \\
\text { Percent (\%) }\end{array}$} \\
\hline & $\begin{array}{l}13 \\
20\end{array}$ & $\begin{array}{l}39.4 \\
60.6 \\
\end{array}$ \\
\hline $\begin{array}{l}\text { VP shunt indications } \\
\text { Intracranial hemorrhage due to prematurity } \\
\text { Congenital anomaly } \\
\text { Intracranial mass } \\
\text { Unknown }\end{array}$ & $\begin{array}{c}11 \\
20 \\
1 \\
1\end{array}$ & $\begin{array}{c}33.3 \\
60.6 \\
3.0 \\
3.0 \\
\end{array}$ \\
\hline $\begin{array}{l}\text { VP shunt change frequency } \\
\text { No VP shunt change } \\
\text { Number of patients with one VP shunt change } \\
\text { Number of patients with } 2 \text { or more VP shunt } \\
\text { changes }\end{array}$ & $\begin{array}{c}16 \\
6 \\
11\end{array}$ & $\begin{array}{l}48.5 \\
18.2 \\
33.3\end{array}$ \\
\hline $\begin{array}{l}\text { Number of patients with previous history of VP } \\
\text { Shunt infection, }\end{array}$ & 12 & 36.4 \\
\hline $\begin{array}{l}\text { Period after last inserted VP shunt (month) } \\
\text { Number of patients with VP shunt in the last } 1 \\
\text { month } \\
\text { The number of patients with VP shunt in the last } \\
\text { 1-3 months } \\
\text { Number of patients with VP shunt in the last } \\
\text { 3-6 months } \\
\text { Number of patients with VP shunt in the last } 6 \text { and } \\
\text { more months }\end{array}$ & 11 & 33.3 \\
\hline $\begin{array}{l}\text { Admission Complaint of Patients* } \\
\text { Nausea and vomiting } \\
\text { Loss of appetite } \\
\text { Fever } \\
\text { Growth around the head } \\
\text { Uneasiness } \\
\text { Change of consciousness } \\
\text { Seizure } \\
\text { Redness at the shunt site } \\
\text { Swelling at the shunt site } \\
\text { No suction } \\
\text { Headache } \\
\text { BSF leak }\end{array}$ & $\begin{array}{c}22 \\
19 \\
17 \\
13 \\
10 \\
6 \\
5 \\
5 \\
4 \\
4 \\
1 \\
1\end{array}$ & $\begin{array}{l}66.7 \\
57.6 \\
51.5 \\
39.4 \\
30.3 \\
18.2 \\
15.2 \\
15.2 \\
12.1 \\
12.1 \\
6.1 \\
3.0\end{array}$ \\
\hline
\end{tabular}

* Multiple complaints were present in the same patient.

intracranial hemorrhage related to prematurity and hydrocephalus due to congenital anomalie and these patients were found to have VP shunt in the first 6 months. The most common complaint was nausea and vomiting (66.7\%), followed by anorexia (57.6\%) and fever (51.5). The most frequent finding in the physical examination was fever (51.5\%) and in $18.2 \%$ of the patients, there was a change in consciousness and only one patient (3\%) had meningeal irritation. The clinical and demographic characteristics of patients with VP shunt infection were shown in Table 1. In our study, median values of CRP, ESR, procalcitonin and white blood cell counts of patients with VP shunt infection were within normal limits. Laboratory data of 
patients is shown in Table 2. The mean platelet counts of patients with ventriculoperitoneal shunt infection before treatment were $521.969 \pm 143.697 \mu \mathrm{L}$ (min-max: 256.000-854.000 $\mu \mathrm{L})$ and thrombocytosis was present in 25 (75.7\%) patients. The difference between thrombocyte values before and after treatment and pretreatment and control group thrombocyte values was significant $(p=0.001)$. When MPV values before and after treatment of patients with ventriculoperitoneal shunt infection were compared, mean MPV value before treatment was $9.58 \mathrm{fL}$, mean MPV after treatment was $9.87 \mathrm{fL}$ and the difference was significant $(p=0.027)$. There was no significant difference between pre- and post-treatment PDR values. No significant difference was found between the control group and the MPV and PDR values of the patients before treatment. Thrombocyte, MPA, and PDR values of the patients before and after treatment and thrombocyte, MPA, and PDR values of the control group were shown in Table 3.

In 23 (69.7\%) of the patients with VP shunt infection, reproduction was detected in the BSF culture and the most common factor was Staphylococcus epidermidis (57.6\%). Distribution of microorganisms reproducing in BSF culture is shown in Table 4. It was determined that the shunt of all patients diagnosed with VP shunt infection was removed and the patients

Table 2. Laboratory values of patients with ventriculoperitoneal shunt infection

\begin{tabular}{|c|c|c|}
\hline Laboratory values & $\begin{array}{l}\text { Number of } \\
\text { patients } \\
\text { examined (n) }\end{array}$ & \\
\hline $\begin{array}{l}\text { Number of white blood cell } \\
\text { count }\left(/ \mathbf{m m}^{\mathbf{3}}\right) \\
\text { Median } \\
\text { Min-max }\end{array}$ & 33 & $\begin{array}{c}13160 \\
5560-36490\end{array}$ \\
\hline $\begin{array}{l}* \text { * } \mathbf{R P}(\mathbf{m g} \mathbf{d} \mathbf{d L}) \\
\text { Median } \\
\text { Min-max }\end{array}$ & 28 & $\begin{array}{c}1.18 \\
0.1-8.7\end{array}$ \\
\hline $\begin{array}{l}\text { Procalcitonin } \mathbf{( n g / d \mathbf { l } )} \\
\text { Median } \\
\text { Min-max }\end{array}$ & 16 & $\begin{array}{c}0.1 \\
0.05-23.1\end{array}$ \\
\hline $\begin{array}{l}\text { *ESR rate }(\mathbf{m m} / \mathbf{h}) \\
\text { Median } \\
\text { Min-max }\end{array}$ & 24 & $\begin{array}{c}8.5 \\
2-88\end{array}$ \\
\hline $\begin{array}{l}* * \text { BSF glucose }(\mathbf{m g} \mathbf{g} \mathbf{d L}) \\
\quad \text { Mean } \pm S D\end{array}$ & 33 & $33.9 \pm 21.3$ \\
\hline $\begin{array}{l}\text { BSF protein }(\mathbf{m g} \mathbf{g} \mathbf{d L}) \\
\text { Median } \\
\text { Min-max }\end{array}$ & 33 & $\begin{array}{c}181 \\
8.3-2743\end{array}$ \\
\hline 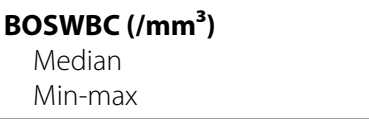 & 33 & $\begin{array}{c}50 \\
0-1000\end{array}$ \\
\hline \multicolumn{3}{|c|}{$\begin{array}{l}{ }^{*} \text { ESR: Erythrocyte sedimentation rate. } \\
{ }^{* *} \text { CRP: C-Reactive protein. } \\
\text { *** BSF: Brain spinal fluid. }\end{array}$} \\
\hline
\end{tabular}

had a reservoir inserted into the ventricle for the removal of BSF. It was determined that intravenous antibiotic treatment was started and intrathecal antibiotic treatment through the reservoir was administrated to all patients. The mean length of hospitalization was $43.3 \pm 23.1$ days. After the treatment, all patients were discharged with healing and $4(12.1 \%)$ patients developed VP shunt infection during follow-up.

\section{Discussion}

In the present study, $93.9 \%$ of 33 patients examined had intracranial hemorrhage due to prematurity and hydrocephalus due to congenital anomalies. The median age of the patients was 8 months and VP shunt was inserted during the first 6 months of their life. One of the most important factors that increase the risk of VP shunt infection in children is age. VP shunt insertion prior to six months was considered a risk for VP shunt infection development. The smaller the age of ventriculoperitoneal shunt insertion, the higher the infection rate is monitored, especially in premature infants and even in low birth weight premature infants $(<1500 \mathrm{~g})$. It has also been shown that the risk of VP shunt infection increases more in premature cases with hydrocephalus after intracranial hemorrhage $(1,14-16)$. It was determined that $69.6 \%$ of the patients had shunt change in the last 3 months and $36.4 \%$ in the last month. Ventriculoperitoneal shunt is most commonly infected with skin colonization and therefore, the risk of developing VP shunt infection is reported to be higher in the first few months after VP shunt insertion. It has been reported that 70\% of ventriculoperitoneal shunt infections developed in the first two months, but $10 \%$ developed after the first year (17-21). In a 6-year cohort study in Korea, it was reported that $91.4 \%$ of VP shunt infections developed within the first 3 months after shunt insertion (22). According to the studies in Turkey, $71.4 \%$ of the VP shunt infections developed during the first 4 months after the insertion and $49,8 \%$ developed in the first following month $(23,24)$. These findings reveal the importance of sterility, which is a preventable risk factor. Previous shunt infection and recurrent shunt changes are another risk factor for VP shunt infection. It was stated that $84.5 \%$ of patients who had been followed up for approximately 20 years after ventriculoperitoneal shunt insertion required one or more VP shunt changes, and VP shunt infection was the cause of VP shunt failure in $9 \%$ of the patients and $4.7 \%$ of the patients had 10 or more shunt changes (25). In our study, $36.4 \%$ of patients had a history of VP shunt infection. $51.5 \%$ of patients had a history of one or more VP shunt changes. The most common cause of ventriculoperitoneal shunt infections is coagulase negative staphylococci found in the normal flora of the skin and the most common microorganisms isolated are S. epidermidis and Staphylococcus aureus. Propionibacterium types in the nor- 
Table 3. Thrombocyte, MPV, and TDA values of patients with ventriculoperitoneal shunt infection before and after treatment and the control group

\begin{tabular}{|c|c|c|c|c|c|}
\hline Platelet parameter & Pretreatment & Post-treatment & Control & $\mathbf{p}^{*}$ & $\mathbf{p}^{* *}$ \\
\hline $\begin{array}{l}\text { Platelet count }(\mu \mathrm{L}) \\
\text { Average } \pm S D\end{array}$ & $521.969 \pm 143.697$ & $390.000 \pm 98.636$ & $363.031 \pm 82.506$ & 0.001 & 0.001 \\
\hline $\begin{array}{l}\text { MPV (fL) } \\
\text { Average } \pm \text { SD }\end{array}$ & $9.58 \pm 1.08$ & $9.87 \pm 1.0$ & $9.23 \pm 1.37$ & 0.027 & 0.25 \\
\hline $\begin{array}{l}\text { PDR (\%) } \\
\text { Average } \pm \text { SD }\end{array}$ & $11.34 \pm 2.77$ & $11.8 \pm 2.2$ & $12.43 \pm 3.26$ & 0.12 & 0.24 \\
\hline
\end{tabular}

Table 4. Microorganisms produced in cerebrospinal fluid of patients

\begin{tabular}{|l|c|c|}
\hline Microorganism reproducing & Number (n) & Percent (\%) \\
\hline Staphylococcus epidermidis & 19 & 82.6 \\
\hline Enterococcus types & 2 & 8.6 \\
\hline Escherichia coli & 1 & 4.3 \\
\hline Pseudomonas aeruginosa & 1 & 4.3 \\
\hline
\end{tabular}

mal flora of the skin may be involved in VP shunt infections. Except for gram-positive bacteria, especially Escherichia coli and other enteric rods are gram-negative bacteria that may be involved in the etiology of VP shunt infection (3). In our study, the active microorganism was detected in BSF of $69.6 \%$ of the patients and the most common microorganism was S. epidermidis (82.6\%). The active microorganism in $8.6 \%$ of our patients was Enterococcus types, in $4.3 \%$ was E. coli and in $4.3 \%$ was Pseudomonas aeruginosa. In a multicentre study conducted in our country, the active microorganism was isolated in $51 \%$ of the patients. The most common isolated agent in this study was $42.5 \%$ coagulase negative staphylococci and $14.9 \%$ P. aeruginosa and $10.1 \%$ Klebsiella pneumoniae, followed by $10.1 \%$ S. aureus (24).

The clinical findings of patients with VP shunt infections vary according to the patient's age, virulence of the microorganism and the type of shunt. In ventriculoperitoneal shunt infections, complaints such as headache, nausea, vomiting, change in consciousness and seizures may develop due to increased intracranial pressure as a result of blockage of the shunt. Fever may not be observed in every patient. Local or systemic signs and symptoms secondary to the site of the distal end of the shunt (peritoneum, pleura, and atrium) may develop (12). Nausea and vomiting in our patients were the most common complaint $(66.7 \%)$. Fever was present in $51.5 \%$ of the patients. VP shunt infection was more prominent due to the local findings on the skin in the region where the shunt was localized (15.2\%), growth around the head as a result of shunt failure (39.4\%) and seizures (15.2\%), change in consciousness (18.2\%). Since the circulation of the BSF between the ventricles and the meninges continues, the signs of meningeal irritation are not usually seen. In our study, only one patient had signs of meningeal irritation on physical examination. In the studies, it was reported that the most common sign of VP shunt infections was fever in the rate of $37.2-95 \%$. In these studies, local inflammation findings were reported to be $3.4-34.3 \%$, vomiting was $6.5-82.5 \%$, consciousness change was $4.1-55 \%$, seizure rate was reported as $17.1-47.5 \%(22,24,26,27)$. There is less inflammation in ventriculoperitoneal shunt infections than in bacterial meningitis. Therefore, the number of white blood cells in BSF is less than that of bacterial meningitis and may not be pleocytosis. It is difficult to evaluate the parameters of the cerebrospinal fluid. There is no culture reproduction at all times. Normal phase of acute phase reactants does not exclude the diagnosis of VP shunt infection $(12,28)$. In our study, the median values of CRP, procalcitonin and ESR levels of the patients investigated were within normal limits.

Non-specific signs and symptoms in ventriculoperitoneal shunt infections, especially in children, often delay the diagnosis and require high suspicion for diagnosis. In our study, we examined the changes in platelet parameters in the diagnosis of VP shunt infection. There was significant thrombocytosis in the patients when the values of the patient at the time of admission were compared with post-treatment values. Thrombocyte count was significantly higher in patients with VP shunt infection compared to the control group. Thrombocytosis can be seen in many infectious diseases in children, especially in closed area infections such as bones, joints and pleura. In previous studies, it has been shown that reactive larger platelets are generated by cytokines such as IL3-IL6 released secondary to inflammation $(29,30)$. We thought that there might be reactive thrombocytosis due to infection in our patients. Reactive thrombocytosis is generally expected to cause an increase in platelet parameters. In our study, the initial MPV values of our patients were found to be lower than those observed before discharge and this difference was significant. There was no difference between the PDR values of the patients before and after discharge. Also, there was no significant difference between the control group consisting of 
healthy children of similar age group in term os MPV and PDR values. In the literature, we found only one study that examined the platelet parameters in VP shunt infection. Çelik and colleagues, as in our study similar, have found that despite the increased platelet count, MPV was found to be lower than the control group (31).

In a study evaluating adult patients with bacterial meningitis and tuberculosis meningitis, platelet count was lower and MPV was higher in patients with bacterial meningitis compared to patients with tuberculous meningitis and healthy control group (32). MPV was found to be high in bacterial bloodstream infections and sepsis and it was shown to be important for prognosis (33-35). In a study evaluating 196 children diagnosed with acute community-acquired pneumonia, MPV values were found to be higher in the hospitalized patients with severe pneumonia than in outpatients. Patients with acute community-acquired pneumonia had lower MPV values than healthy control group (36). In patients who were followed up with peritonsillar abscess diagnosis, MPV values before treatment were found to be higher than those after treatment and control group (37). In studies evaluating platelet parameters in acute infections, quite different results have been obtained. However, these studies were generally performed retrospectively and with a small number of patients. The limitation of our study was the retrospective nature and a small number of patients.

\section{Conclusion}

There are no specific clinical signs and laboratory investigations in the diagnosis of VP shunt infections, but early diagnosis and treatment are essential for prognosis. Since platelet parameters can be measured via complete blood count, they are very cheap and easy to obtain. Platelet count and MPV value can be used as a laboratory sign in early diagnosis of VP shunt infections, but prospective studies are needed on this subject.

Ethics Committe Approval: Ethics committee approval was obtained with Decision No: 6 at the meeting of Cukurova University Medical Faculty Non-invasive Clinical Researches Ethics Committee dated 05.10.2018.

Informed Consent: Patient consent was obtained.

Peer-review: Externally peer-reviewed.

Author Contributions: Concept - ÖÖG, ZH, KMÖ, DA, EK; Design ÖÖG, ZH, KMÖ, DA, EK; Supervision - ÖÖG, ZH, KMÖ, DA, EK; Funding - ÖÖG; Materials - ÖÖG, ZH; Data collection and/or processing - ÖÖG; Analysis and/or Interpretation - ÖÖG, ZH, EK; Literature review - ÖÖG; Writing - ÖÖG, EK; Critical review - ÖÖG, ZH, KMÖ, DA, EK.

Conflict of Interest: No conflict of interest was declared by the authors.
Financial Disclosure: The authors declared that this study has received no financial support.

\section{References}

1. Vinchon $M$, Dhellemmes $P$. Cerebrospinal fluid shunt infection: Risk factors and long-term follow-up. Childs Nerv Syst 2006;22:692-7.

2. Tunkel $A R$, Hasbun $R$, Bihimraj $A$, et al. Infectious Diseases Society of America's Clinical Practice Guidlines for Healthcare- Associated Ventriculitis and Menengitis. Clin Infect Dis 2017.

3. McGirt MJ, Zaas A, Fuchs HE, George TM, Kaye T, Sexton DJ. Risk factors for pediatric ventriculoperitoneal shunt infection and predictors of infectious pathogens. Clin Infect Dis 2003;36:858-62.

4. Prusseit J, Simon M, von der Brelie C, et al. Epidemiology, prevention and management of ventriculoperitoneal shunt infections in children. Pediatr Neurosurg 2009;45:325-36.

5. Rowin ME, Patel VV, Christenson JC. Pediatric intensive care unit nosocomial infections: epidemiology, sources and solutions. Crit Care Clin 2003;19:473-87.

6. Simon TD, Hall M, Riva-Cambrin J, et al. Infection rates following initial cerebrospinal fluid shunt placement across pediatric hospitals in the United States. Clinical article. J Neurosurg Pediatr 2009;4:156-65.

7. Simon TD, Butler J, Whitlock KB, et al. Risk factors for first cerobrospinal fluid shunt infection: findings from a multi-center prospective cohort study. J Pediatr 2014;164:1462-8.

8. Murgan YG, Snowden JN. Ventricular shunt infections: Immunopathogenesis and clinical management. J Neuroimmunol 2014;276:1-8.

9. Gasparyan AY, Ayvazyan L, Mikhailidis DP, Kitas GD. Mean platelet volume: a link between thrombosis and inflammation? Curr Pharm Des 2011;17:47-58.

10. Leader A, Pereg D, Lishner M. Are platelet volume indices of clinical use? A multidisciplinary review. Ann Med 2012;44:805-16.

11. Kulkarni AV, Drake JM. Cerebrospinal fluid shunt infection: A Prospective study of risk factors. J Neurosurg 2001;94:195-201.

12. Baddour LM, Flynn PM, Fekete T. Infections of cerebrospinal fluid shunts and other devices. Calderwood SB, Edwards MS, Mitty J (ed). Available from: 10.08.2018 www.uptodate.com/contents/infectionsof-cerebrospinal-fluid-shunts-and-other devices.

13. Sutor AH. Thrombocytosis. In: Lilleyman JS, Hann IM, Blanchette VS (eds). Pediatric Hematology. Churchill Livingstone, London, Dinburgh, New York. Philadelphia. Sydney, Toronto 1999;455-64.

14. Boynton BR, Boynton CA, Merritt TA, Vaucher YE, James HE, Bejar $R F$. Ventriculoperitoneal shunts in low birth weight infants with intracranial hemorrhage. Neurodevelopmentaloutcome. Neurosurgery 1986;18:141-5.

15. Enger PO, Svendsen F, Wester K. CSF shunt infections in children: Experiences from a population-based study. Acta Neurochir 2003;145:243-8.

16. Köksal V, Öktem S. Ventriculosubgaleal shunt procedure and its long-term outcomes in premature infants with posthemorrhagic hydrocephalus. Childs Nerv Syst 2010;26:1505-15.

17. Conen A, Walti LN, Merlo A, Fluckiger U, Battegay M, Trampuz A. Characteristics and treatment outcome of cerebrospinal fluid shuntassociated infections in adults: A retrospective analysis over an 11-year period. Clin Infect Dis 2008;47:73-82.

18. Choux M, Genitori L, Long D, Lena G. Shunt implantation: reducing the incidence of shunt infection. J Neurosurg 1992;77:875-80. 
19. Kang JK, Lee IW. Long-term follow-up of shunting therapy. Childs Nerv Syst 1999;15:711-17.

20. Kontny U, Hofling B, Gutjahr P, Voth D, Schwarz M, Schmitt HJ. CSF shunt infections in children. Infection 1993;21:89-92.

21. Piatt JH, Carlson CV. A search for determinants of cerebrospinal fluid shunt survival: $A$ retrospective analysis of a 14 year institutional experience. Pediatr Neurosurg 1993;19:233-42.

22. Lee JK, Seok JY, Lee $J H$, et al. Incidence and risk factors of ventriculoperitoneal shunt infections in children: a study of 333 consecutive shunts in 6 years. J Korean Med Sci 2012;27:1563-8.

23. Turgut $M$, Alabaz D, Erbey $F$, et al. Cerebrospinal fluid shunt infections in children. Pediatr Neurosurg 2005;41:131-6.

24. Yakut N, Soysal A, Kepenekli-Kadayıfçı E, Dalgıç N, Yılmaz Çiftdoğan D, Karaaslan A. Ventriculoperitoneal shunt infections and reinfections in children: a multicentre retrospective study. Br J Neurosurg 2018;32:196200.

25. Stone JJ, Walker CT, Jacobson M, Phillips V, Silberstein HJ. Revision rate of pediatric ventriculoperitoneal shunts after 15 years. J Neurosurg Pediatr 2013;11:15-9.

26. Telhan L, Çavuşoğlu F, Müslüman $M$, Türkmenoğlu $O$, Çetinkaya $F$. Ventriküloperitoneal Şant Enfeksiyonu Gelişmiş Çocukların Etiyolojik ve Prognostik Açılardan Değerlendirilmesi. Çocuk Enf Derg 2010;4:100-3.

27. Odio C, McCracken GH, Nelson JD. CSF shunt infections in pediatrics: a seven year experience. Am J Dis Child 1984;138:1103-8.

28. Tatara $\mathrm{R}$, Imai H. Serum C-reactive protein in the differential diagnosis of childhood meningitis. Pediatr Int 2000;42:541-6.

29. Wang JL, Huang LT, Wu KH, Lin HW, Ho MY, Liu HE. Associations of reactive thrombocytosis with clinical characteristics in pediatric diseases. Pediatr Neonatol 2011;52:261-6.
30. Debili N, Massé JM, Katz A, Guichard J, Breton-Gorius J, Vainchenker W. Effect of the recombinant hematopoetic growth factors interleukin-3, interleukin-6, stem cell factor and leukemia inhibitory factor on the megacaryocytic differantiation of CD34+ cells. Blood 1993;82:84-95.

31. Celik U, Celik T, Tolunay O, Dönmezer C, Gezercan Y, Mert K. Platelet Indices in the Diagnosis of Ventriculoperitoneal Shunt Infection in Children. Turk Neurosurg 2017;27:590-3.

32. Camara-Lemarroy CR, Delgado-Garcia G, Cruz-Gonzalez JG, VillarrealVelazquez HJ, Gongora-Rivera F. Mean platelet volume in the differential diagnosis of tuberculous and bacterial meningitis. J Infect Dev Ctries 2017;11:166-72.

33. Kitazawa $T$, Yoshino $Y$, Tatsuno $K$, Ota $Y$, Yotsuyanagi $H$. Changes in the mean platelet volume levels after bloodstream infection have prognostic value. Intern Med 2013;52:1487-93.

34. Orfanu AE, Popesccu C, Leusteon A, et al. The importance of haemogram parameters in the diagnosis and prognosis of septic patients. J Crit Care Med (Targu Mures) 2017;3:105-10.

35. Aydemir H, Piskin N, Akduman D, Kokturk F, Aktas E. Platelet and mean platelet volume kinetics in adult patients with sepsis. Platelets 2015;26:331-5.

36. Karadag-Oncel E, Ozsurekci Y, Kara A, Karahan S, Cengiz AB, Ceyhan M. The value of mean platelet volume in the determination of community acquired pneumonia in children. Ital J Pediatr 2013;39:16.

37. Şentürk M, Azgın I, Övet G, Alataş N, Ağırgöl B, Yılmaz E. The role of the mean platelet volüme and neutrophile-to-lymphocyte ratio in peritonsillar abscesses. Braz J Otorhinolaryngol 2016;82:662-7. 